22 | 1995

Varia

\title{
Boissons des hommes, ferment du savoir
}

\section{Marie-Claude Mahias}

\section{OpenEdition}

Journals

Édition électronique

URL : https://journals.openedition.org/tc/637

DOI : $10.4000 /$ tc. 637

ISSN : 1952-420X

\section{Éditeur}

Éditions de l'EHESS

\section{Édition imprimée}

Date de publication : 1 mars 1995

ISSN : 0248-6016

\section{Référence électronique}

Marie-Claude Mahias, « Boissons des hommes, ferment du savoir », Techniques \& Culture [En ligne], 22 I 1995, mis en ligne le 05 janvier 2006, consulté le 29 septembre 2022. URL : http://

journals.openedition.org/tc/637 ; DOI : https://doi.org/10.4000/tc.637

Ce document a été généré automatiquement le 29 septembre 2022.

Tous droits réservés 


\title{
Boissons des hommes, ferment du savoir
}

\author{
Marie-Claude Mahias
}

